\title{
Przyczynek do relacji tatarsko- -karaimskich w okresie międzywojennym i późniejszym. Hachan Hadży Seraja Szapszal i mufti dr Jakub Szynkiewicz
}

\author{
Selim Chazbijewicz \\ Uniwersytet Warmińsko-Mazurski \\ Wydział Nauk Społecznych
}

\begin{abstract}
An Addendum to Tatar-Karaim Relations
during and after the Interwar Period. Hakhan Haji Seraya Shapshal and the Grand Mufti Dr Jakub Szynkiewicz
\end{abstract}

Summary: This article discusses the relations between Crimean Karaites and Tatars in Poland in the more distant past, during the the Second Polish Republic and also throughout World War II. It describes the relationship between the spiritual leader of the Karaites (Karaims) Haji Seraya Shapshal and the Grand Mufti of all Muslims in Poland - Jakub Szynkiewicz, their relationship during World War II, and additionally the role played by the Tatars in saving the the Karaims from extermination at the hands of the Nazi Germans in Vilnius in 1941-1944. Moreover, the author mentions scholars and orientalists with a Karaim background writing about Polish Tatars. This scholarly piece should encourage further research on this issue. It appears to be an academic problem worth investigating.

Keywords: Crimean Tatars, Crimean Karaites (Karaims), Hajji Seraya Shapshal, the Grand Mufti in Poland Jakub Szynkiewicz

Karaimi i Tatarzy są sobie pokrewni zarówno pod względem etnicznym, językowym jak i religijnym. Oba narody mówią pokrewnymi językami turkijskimi, 
oba dzieliły podobny albo nawet przez pewien czas wspólny los polityczny na Krymie, a także w Wielkim Księstwie Litewskim. Również pod względem religijnym można znaleźć wspólne obszary. Założyciel religii karaimskiej, Anan ben Dawid był uczniem Abu Hanify, jednego z czterech założycieli szkół prawno-teologicznych w sunnickim islamie. Stąd karaimi, jak pisał Ananiasz Zajączkowski, uznają misję proroczą Muhammada. I stąd też wyjątkowe traktowanie Karaimów zarówno w Chanacie Krymskim, jak i w Turcji Osmańskiej. Również na gruncie kultury polskiej i dawnego Wielkiego Księstwa Litewskiego dała się zauważyć pewna niepisana wspólnota tatarsko-karaimska, polegająca na zdecydowanym i konsekwentnym monoteizmie, ikonoklazmie oraz uznawaniu misji proroczej Muhammada. Wspólnota ta polegała także na etniczności, języku, który Tatarzy z czasem zatracili oraz wojennym zajęciu zwłaszcza w początkowym okresie historii - obu grup narodowych w Wielkim Księstwie Litewskim.

Warto także podkreślić pewną wspólnotę losów karaimsko-tatarskich na Krymie. Rząd Karaima, premiera Solomona Kryma w 1918 r. był następnym gabinetem rady ministrów po rządach tatarskich generała Macieja Sulkiewicza.

W okresie międzywojennym karaimski przywódca, hachan Seraja Szapszał, również wybitny turkolog i orientalista, publikował w pierwszym tomie „Rocznika Tatarskiego”, wydawnictwa Rady Centralnej Związku Kulturalno-Oświatowego Tatarów Rzeczypospolitej Polskiej. Tom pierwszy tego „Rocznika Tatarskiego", którego redaktorem i faktycznym wydawcą był Leon Najman Mirza Kryczyński, ukazał się w Wilnie w 1932 r. Seraja Szapszał publikował tam artykuł pt. O zatraceniu języka ojczystego przez Tatarów w Polsce, w którym postawił tezę, iż przyczynę asymilacji językowej Tatarów w byłym Wielkim Księstwie Litewskim stanowiły małżeństwa mieszane. Teza ta, podważana przez współczesnych badaczy, była jednakże przez długi okres czasu przyjętą jako pewnik tak przez badaczy, jak i samych Tatarów.

W drugim tomie „Rocznika Tatarskiego" publikował, młody wtedy, docent Uniwersytetu Warszawskiego, Ananiasz Zajączkowski. Tom drugi tego wydawnictwa wydany był w Zamościu w 1935 r. Zajączkowski opublikował w nim artykuł Elementy tureckie na ziemiach polskich.

Jakub Szynkiewicz, mufti polskich muzułmanów od grudnia 1925 r., spotykał się z Hadży Serają Szapszałem zarówno podczas uroczystych, oficjalnych ceremonii państwowych w Wilnie, jak i na gruncie prywatnym. Obaj z wykształcenia byli orientalistami. Publikowali artykuły i rozprawy dotyczące języka i literatury oraz religii islamskiej i karaimskiej. Do dzisiaj w wileńskiej dzielnicy Lipówka znajduje się wspólny tatarsko-karaimski cmentarz, gdzie m.in. 
pochowany został Seraja Szapszał. Znajdują się tam również groby krewnych autora niniejszych słów. Podobna nekropolia miała powstać w okresie powojennym w Gdańsku-Oliwie na tamtejszym cmentarzu (warto również pomyśleć współcześnie o tatarsko-karaimskim muzeum, pomyślanym jako profesjonalna, naukowa, państwowa instytucja). Relacje osobiste łączyły także Seraję Szapszała z ówczesnym imamem wileńskim Ibrahimem Smajkiewiczem.

Jakub Szynkiewicz, co jest istotne dla jego późniejszej biografii, posiadał rodzonego brata, Macieja, który razem z nim przebywał na Krymie, a w roku 1918 został przewodniczącym Związku Tatarów Litewskich w Symferopolu. Maciej, po przejęciu władzy na półwyspie przez bolszewików w 1920 r., nie zdołał wrócić do Polski. W 1928 r. został aresztowany za nacjonalizm tatarski, trockizm i szpiegostwo na rzecz organizacji białogwardyjskich. Aresztowany został też jego syn, Edige. Obaj trafili na zesłanie pod koło polarne. Maciej nie przeżył tego obozu, jednakże młody Edige zdołał uciec i przedostawszy się przez całe terytorium Związku Sowieckiego, przekroczył nielegalnie granicę z Iranem (wtedy jeszcze Persją) na Kaukazie. W Teheranie zgłosił się do polskiej ambasady i otrzymał pomoc. W roku 1936 był już w Polsce i tu podjął studia w Szkole Nauk Politycznych przy Instytucie Badań Europy Wschodniej w Wilnie. Związał się jako współorganizator ze Związkiem Młodzieży Tatarskiej w Wilnie. Nie jest wykluczone, że Edige Szynkiewicz już w tym okresie podjął współpracę z wywiadem niemieckim, jak i tureckim. Po wybuchu II wojny światowej wyjechał z Polski jako bezpaństwowiec razem z personelem ambasady tureckiej. W latach 1941 i 1942 za pośrednictwem von Pappena, ambasadora Rzeszy w Ankarze, podjął rozmowy w Berlinie z władzami niemieckimi w sprawie organizacji oddziałów ochotniczych w Wehrmachcie, złożonych z jeńców sowieckich pochodzenia tatarskiego. Posiadał pełnomocnictwo emigracji politycznej Tatarów Krymskich w Turcji i ciche przyzwolenie rządu tureckiego. Otrzymał oficjalną funkcję reprezentanta tatarskich interesów narodowych przy Niemieckim Sztabie Dowództwa Wojsk Lądowych. Kiedy w roku 1942 generał von Manstein zajmuje Krym, Edige Szynkiewicz przenosi się na półwysep, gdzie staje się szarą eminencją zorganizowanego przez Niemców samorządu tatarskiego - Komitetu Muzułmańskiego. Uczestniczy też w wydawaniu miesięcznika „Azad Kyrym” (Wolny Krym). Po ewakuacji Krymu w 1944 r. Edige Szynkiewicz uczestniczy w rozmowach na temat organizacji Tatarskiej Górskiej Brygady Waffen SS, sformowanej już na Węgrzech. Po zakończeniu II wojny światowej osiadł na stale w Monachium, gdzie współorganizował tatarską rozgłośnię radia „Svoboda” i zajmował się pracą naukową w monachijskim Instytucie Badań nad Związkiem Sowieckim. Zmarł 22 czerwca 1980 r. W roku 2007 Tatarzy krymscy sprowadzili 
jego prochy na Krym i pochowali w Bachczysaraju, na cmentarzu zasłużonych dla sprawy narodowej obok mauzoleum chana Mengli Gereja.

Wuj Edige, mufti Jakub Szynkiewicz był w dużej mierze inspirowany przez siostrzeńca. Po wybuchu wojny również podjął współpracę z Niemcami. Przypomniał sobie o nim jego dawny kolega, wtedy minister propagandy Rzeszy. Jakub Szynkiewicz został mianowany przez władze niemieckie muftim Ostlandu, czyli okupowanego terytorium wschodnich terenów: Polski, Białorusi, Litwy i krajów bałtyckich. W latach 1943-1944 Jakub Szynkiewicz zaangażował się w tworzenie Związku Młodzieży Tatarskiej, organizacji wzorowanej na Hitlerjugend. Jako mufti Ostlandu podlegał wielkiemu muftiemu Jerozolimy, Aminowi Al-Husejniemu, którego władze niemieckie wyznaczyły na zwierzchnika wszystkich muzułmanów na terenach zajętych przez III Rzeszę. Al-Husejni otrzymał od Himmlera tytuł Obergruppenführera SS jako nominalny szef Legionu Arabskiego Waffen SS. Był też wujkiem nieżyjącego już przywódcy Palestyńczyków, Jasira Arafata. W roli muftiego Ostlandu Szynkiewicz udzielił paru wywiadów dla ówczesnej prasy niemieckiej. W 1944 r., kiedy Niemcy ewakuowali się z Wilna, wyjechał razem z nimi. Poprzez Wiedeń i Rzym trafił do Egiptu, gdzie mieszkał do 1952 r. Po zamachu stanu i przejęciu władzy przez Nasera, wyjechał do USA, gdzie zmarł w roku 1966. W okresie swojego urzędowania jako mufti Ostlandu, korzystając ze swoich znajomości z Goebbelsem, przyczynił się do ocalenia od zagłady Karaimów wileńskich, których Niemcy, biorąc ich za Żydów, chcieli eksterminować. Wskutek telefonicznej interwencji Szynkiewicza bezpośrednio u Goebbelsa, władze niemieckie zarządziły w 1943 r. badania rasowe, które niezbicie potwierdziły przynależność Karaimów do rasy ałtajskiej, z której wywodzą się Turcy i Tatarzy. W ten sposób zostali oni wyłączeni z eksterminacji. Dzięki powyższym działaniom wyratowało się też wielu Żydów, którzy albo podawali się za Karaimów albo otrzymywali od muftiego zaświadczenia, że są muzułmanami i dlatego są obrzezani, bowiem islam, podobnie jak judaizm, nakazuje mężczyznom praktykę obrzezania. O takich przypadkach wspominają pamiętnikarze tego okresu, istnieją również relacje samych uratowanych w ten sposób Żydów. Epizod z wyjazdem z Wilna i ewakuacją urzędu muftiego do Wiednia w 1944 r. opisuje wybitny polski pisarz emigracyjny, Józef Mackiewicz w zbiorze artykułów i esejów pt. Droga Pani, w rozdziale pt. „Ostturkmenische Waffen SS”. Mackiewiczowi mufti, a raczej jego zastępca podczas wojny, Borys Urman Emirza Chalecki również pomógł wyjechać, a właściwie uciec przed bolszewikami. Dokumenty, m.in. fotografie dokumentujące wspomniane wyżej badania rasowe znajdują się w archiwach niemieckich. 
Badacze karaimscy zajmowali się także badaniami nad polskimi i innymi Tatarami, co było najpewniej przejawem odczuwanej bliskości etnicznej. Przykładem były zainteresowania Ananiasza Zajączkowskiego, Włodzimierza Zajączkowskiego, Aleksandra Dubińskiego czy Jana Reychmana‥ Karaim i turkolog, badacz dziejów i języka karaimskiego Aleksander Dubiński wiele swoich prac naukowych i popularyzatorskich poświęcił problematyce tatarskiej. Warto także wspomnieć w tym miejscu profesora Włodzimierza Zajączkowskiego, również Karaima, autora pracy pt. Język i folklor Tatarów Dobrudży rumuńskiej. Sam Seraja Szapszał miał o wiele więcej politycznego rozsądku niż mufti Szynkiewicz. Po wojnie został w Wilnie, już sowieckim, nieniepokojony przez NKWD. Zajął się pracą naukową, będąc m.in. współautorem słownika karaimsko-rosyjsko-polskiego. Roztaczał opiekę duszpasterską nad swoimi współwyznawcami, uzupełniał kolekcję orientaliów. Współpracował z wybitnym sowieckim orientalistą, arabistą polskiego pochodzenia, Ignacym Kraczkowskim, autorem przekładu Koranu na język rosyjski. Być może kontakty z Kraczkowskim i jego polityczne koneksje uratowały Seraja Szapszała od więzienia i wywózki do obozu pracy przymusowej. Te sprawy, powiązania i relacje dalej czekają na swojego badacza.

1 Ten ostatni nie był Karaimem - przyp. red. 


\section{Aneks}

$\mathrm{Na}$ fotografii: awers i rewers pocztówki wysłanej z Damaszku przez Seraja Szapszała do imama wileńskiego Ibrahima Smajkiewicza (ze zbiorów autora).
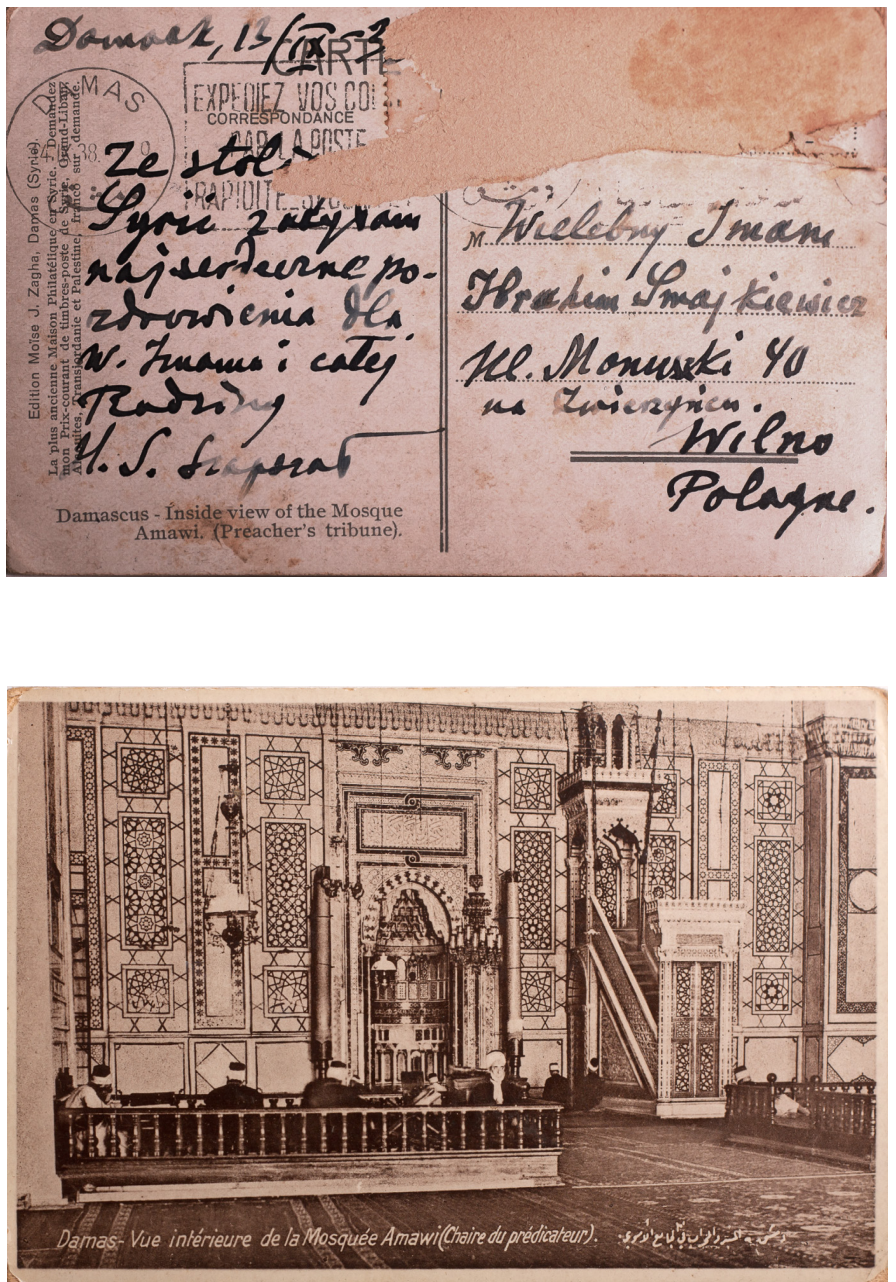